\title{
Synthesis and reactivity of a 1,4-dihydropyrazine derivative
}

\author{
Anabela Rodrigues, Paula M. T. Ferreira and Luís S. Monteiro* \\ Departamento de Química, Universidade do Minho, Gualtar, 4710-057 Braga, Portugal
}

Received 2 April 2004; revised 11 June 2004; accepted 30 June 2004

Available online 31 July 2004

\begin{abstract}
N, N$-Bis-(tert-butoxycarbonyl)-2,5-bis-methoxycarbonyl-1,4-dihydropyrazine can be obtained in high yield by treatment of the methyl ester of $N$-(4-toluenesulfonyl)- $N$-(tert-butoxycarbonyl)- $\alpha, \beta$-didehydroalanine with dimethylaminopyridine and potassium carbonate. This compound was used as substrate in Michael addition reactions with several types of nucleophiles. The electrochemical behaviour of this pyrazine derivative was also studied by cyclic voltammetry and by controlled potential electrolysis.

(C) 2004 Published by Elsevier Ltd.
\end{abstract}

\section{Introduction}

Diazines constitute an important class of heterocyclic compounds present in several natural occurring compounds. Pyrazines are found in the luminescent chromophores of certain marine organisms, ${ }^{1}$ in cephalostatins isolated from Cephalodiscus Gilchrist which are powerful anticancer agents, ${ }^{2}$ in the fungal metabolite aspergillic acid $^{3}$ and in foods as potent flavour components. ${ }^{4}$ 1,4-Dihydropyrazine is an important structural unit of certain redox-active biological molecules such as flavin coenzymes and several marine luciferines. ${ }^{5}$ 1,4-Dihydropyrazine derivatives also constitute interesting electron donors in conducting charge transfer complexes and magnetic materials. The properties of 1,4-dihydropyrazines depend on the nature of the substituents and on the planarity of the ring. When planar, these ring systems can be considered 'anti-aromatic' due to cyclic $8 \pi$-electron conjugation. ${ }^{5}$

Recently, we have demonstrated the versatility of the methyl ester of $N$-(4-toluenesulfonyl)- $N$-(tert-butoxycarbonyl)- $\alpha, \beta$-didehydroalanine $\left[\right.$ Tos- $\Delta$ Ala $\left(N\right.$-Boc)-OMe ${ }^{6}$ as a substrate in Michael addition reactions. This compound is easily prepared in high yield from Tos-Ser-OMe by a ditert-butylpyrocarbonate/dimethylaminopyridine $\left[(\mathrm{Boc})_{2} \mathrm{O} /\right.$ DMAP] mediated dehydration. ${ }^{6}$ Depending on the structure of the nucleophile, several types of compounds can be synthesized from Tos- $\Delta \mathrm{Ala}(N$-Boc)-OMe, namely $\beta$-substituted alanine and dehydroalanine derivatives, ${ }^{7}$ furanic amino acids, which by treatment with TFA yield dehydroproline derivatives ${ }^{8}$ and $\alpha$,-substituted $\beta$-sufinylamino

Keywords: Dehydroalanines; 1,4-Dihydropyrazine; Pyrazine; Michael adddition; Electrolysis.

* Corresponding author. Tel.: + 351253604374; fax: +351253678983; e-mail: monteiro@quimica.uminho.pt acids. $^{8}$ It was also found that Tos- $\Delta$ Ala( $N$-Boc)-OMe in the presence of DMAP undergoes a rearrangement to give the $E$ isomer of the methyl ester of $N$-(tert-butoxycarbonyl)$O$-(4-toluenesulfonyl)- $\alpha, \beta$-didehydroserine. ${ }^{7}$ Here in, we describe the synthesis and discuss the reactivity of $N, N$-bis(tert-butoxycarbonyl)-2,5-bis-methoxycarbonyl-1,4-dihydropyrazine obtained from Tos- $\Delta \mathrm{Ala}(N$-Boc)-OMe.

\section{Results and discussion}

When Tos- $\Delta \mathrm{Ala}(N$-Boc)-OMe (compound 1) was reacted with DMAP in acetonitrile in the presence of an excess of potassium carbonate the product obtained was $N, N$-bis-(tertbutoxycarbonyl)-2,5-bis-methoxycarbonyl-1,4-dihydropyrazine in $89 \%$ yield (compound 2 , Scheme 1). By sampling the reaction mixture and carrying out ${ }^{1} \mathrm{H}$ NMR analysis, it was found that the reaction proceeds via the formation of the methyl ester of $N$-(tert-butoxycarbonyl)- $O$ (4-toluenesulfinyl)- $\alpha, \beta$-didehydroserine. Alternatively, compound $\mathbf{2}$ can be prepared in a one pot procedure from Tos-Ser-OMe by reacting with (Boc) $)_{2} \mathrm{O}$ and DMAP ( 0.1 equiv) in dry acetonitrile for $30 \mathrm{~min}$ and then adding $\mathrm{K}_{2} \mathrm{CO}_{3}$ (6 equiv) and more DMAP (1 equiv) (78\% yield).

The presence of electron withdrawing substituents on 1,4dihydropyrazine systems has a stabilizing effect thus allowing the preparation and isolation of such compounds. ${ }^{5 b}$ In the case of compound $\mathbf{2}$ the stabilizing effect of the ester groups is reinforced by the presence of the Boc groups on the nitrogen atoms. These groups are essential for stabilization of this 1,4-dihydropyrazine system since treatment of compound $\mathbf{2}$ with TFA gave 2,5-bis-methoxycarbonylpyrazine in $71 \%$ yield (compound $\mathbf{3}$, Scheme 2 ). The methoxycarbonyl substituents in compound $\mathbf{3}$ cause the 
<smiles>C=C(C(=O)OC)N(CCCCCCC)C(=O)c1ccccc1</smiles>

1

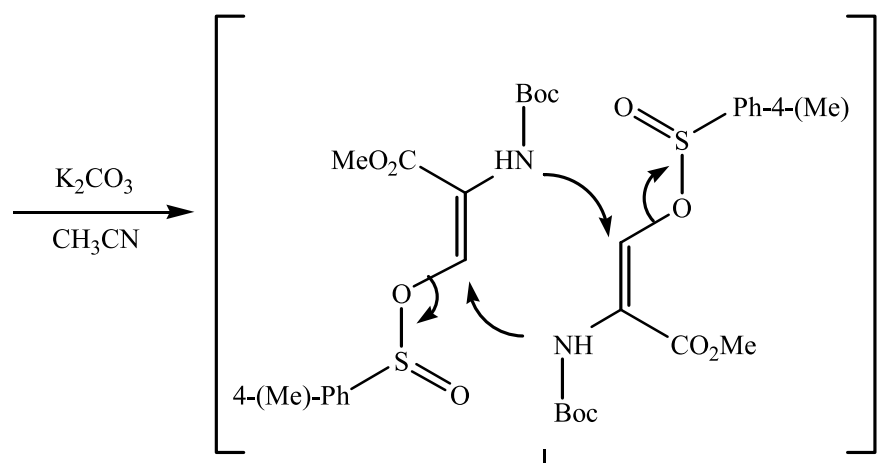

DMAP

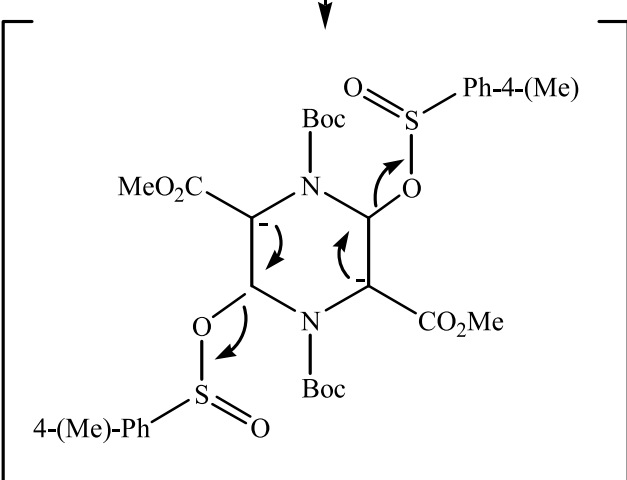

Scheme 1.

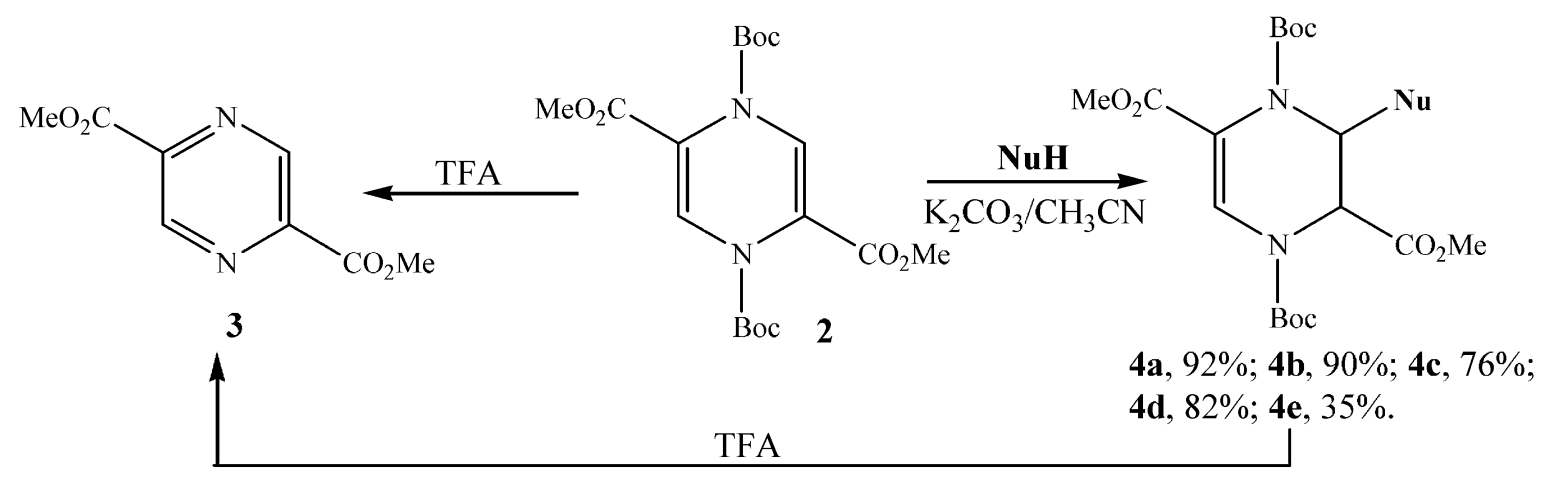

NuH: 1,2,4-triazole, a; 3-formylindole, $\mathbf{b}$; 4-bromothiophenol, $\mathbf{c}$; benzylamine, $\mathbf{d}$; sodium methoxide, e.

Scheme 2.

aromatic protons to show a downfield shift in the ${ }^{1} \mathrm{HNMR}$ spectrum (9.42 ppm in $\mathrm{CDCl}_{3}$ ) when compared with those of unsubstituted pyrazine $\left(8.60 \mathrm{ppm}\right.$ in $\left.\mathrm{CDCl}_{3}\right){ }^{9}$

The four electron-withdrawing groups of compound $\mathbf{2}$ made it possible to use this compound as an electrophile in Michael addition reactions. Thus, compound $\mathbf{2}$ was treated with several types of nucleophiles namely: 1,2,4-triazole, 3 -formylindole, benzylamine, 4-bromothiophenol and sodium methoxide to give one of the diasteriomers of the corresponding 3-substituted-2,5-bis-methoxycarbonyl1,2,3,4-tetrahydropyrazine derivatives in good to high yields (compounds 4a-e, Scheme 2). ${ }^{1} \mathrm{H}$ NMR spectra of these addition products at $25^{\circ} \mathrm{C}$ in $\mathrm{CDCl}_{3}$ showed $4 \mathbf{a}-\mathbf{e}$ to be rotameric mixtures with no coupling between the $2-\mathrm{H}$ and $3-\mathrm{H}$ protons which indicate that the diastereomer obtained corresponds to the trans isomer. ${ }^{1} \mathrm{H}$ NMR analysis of the Michael adducts show that the remaining vinylic proton suffers from a downfield shift (from $7.09 \mathrm{ppm}$ to values ranging from 7.24 to $7.78 \mathrm{ppm}$ ). This has been found in other cases in which cyclic $8 \pi$-electron conjugated systems are reduced to non-aromatic compounds. ${ }^{5 \mathrm{~b}, 10}$ Treatment of compounds $\mathbf{4} \mathbf{c}$ and $\mathbf{4 d}$ with TFA resulted in cleavage of the Boc groups and elimination of the nucleophile giving the pyrazine derivative 3 (76 and $74 \%$, respectively). This indicates that the presence of electron withdrawing 
substituents on the nitrogen atoms is also essential for stabilization of these non-aromatic tetrahydropyrazine systems.

The UV spectrum of compound 2 shows two absorption bands at 225 and $276 \mathrm{~nm}$ (extinction coefficients of 43,265 and $31,720 \mathrm{M}^{-1} \mathrm{~cm}^{-1}$ ) and is similar to the UV spectrum of compound 3 which shows absorption bands at the same wavelengths (extinction coefficients of 34,615 and 23,330 $\mathrm{M}^{-1} \mathrm{~cm}^{-1}$ ) (Fig. 1).

Cyclic voltammetry of compound 2 between -1.0 and
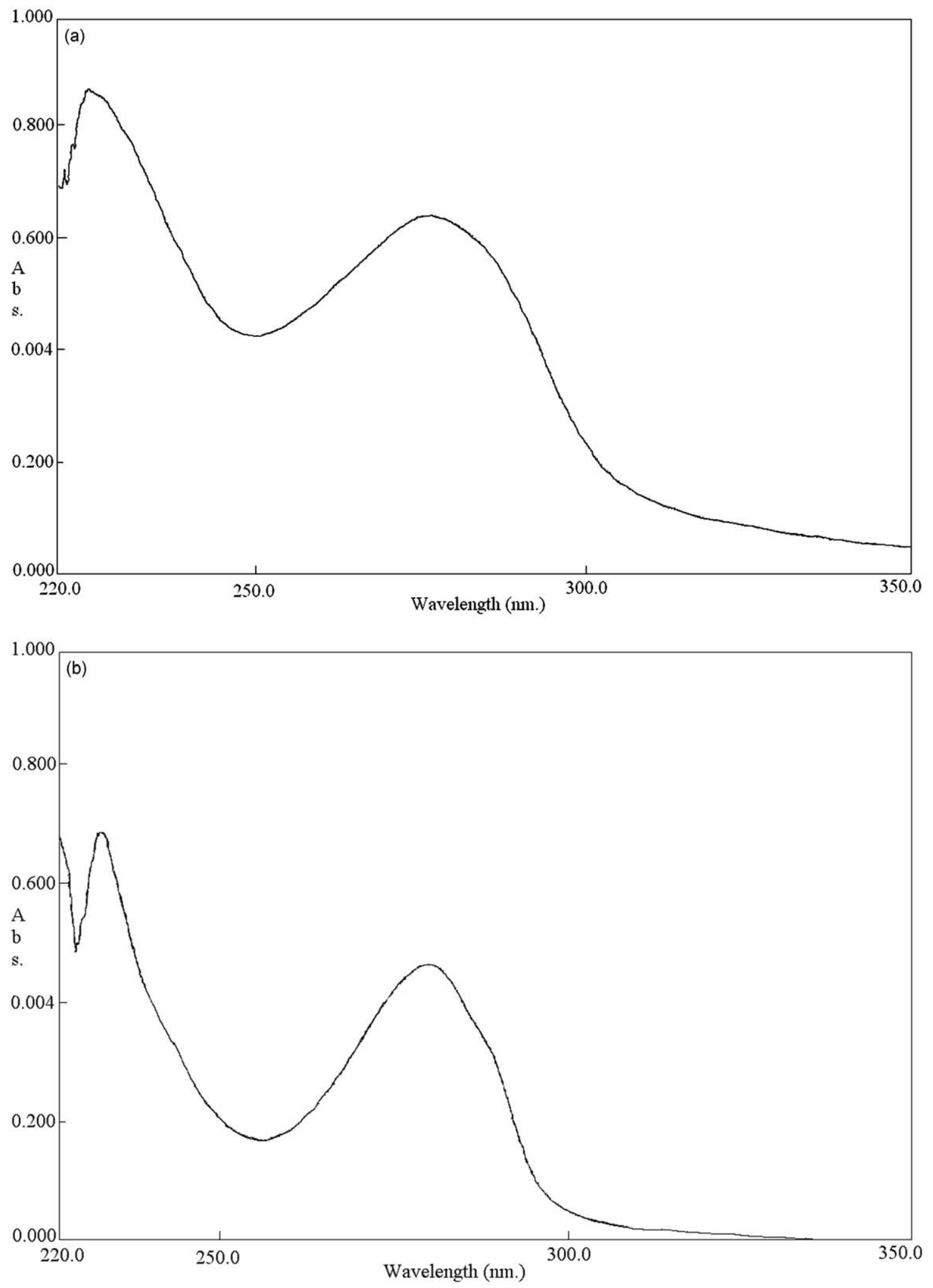

Figure 1. UV spectra of compounds $\mathbf{2}$ and $\mathbf{3}$ in dichloromethane. 
$1.8 \mathrm{~V}$ showed a single oxidation peak at $1.20 \mathrm{~V}$ versus SCE (Fig. 2). The oxidation potential described for $N$-ethyl-1,4dihydropyrazine is $-0.67 \mathrm{~V}$ versus SCE. ${ }^{11}$ Thus, the high potentials for oxidation of compound $\mathbf{2}$ can be assigned to the electron-withdrawing effect of the substituents which makes the loss of electrons more difficult. A potential sweep from 0 to $-2.8 \mathrm{~V}$ showed a reduction peak at $-2.14 \mathrm{~V}$ versus SCE (Fig. 2).

The pyrazine derivative (compound 3) shows no oxidation peak in the range between -1.0 and $1.8 \mathrm{~V}$. A potential sweep from 0 to $-2.8 \mathrm{~V}$ showed two reduction peaks at
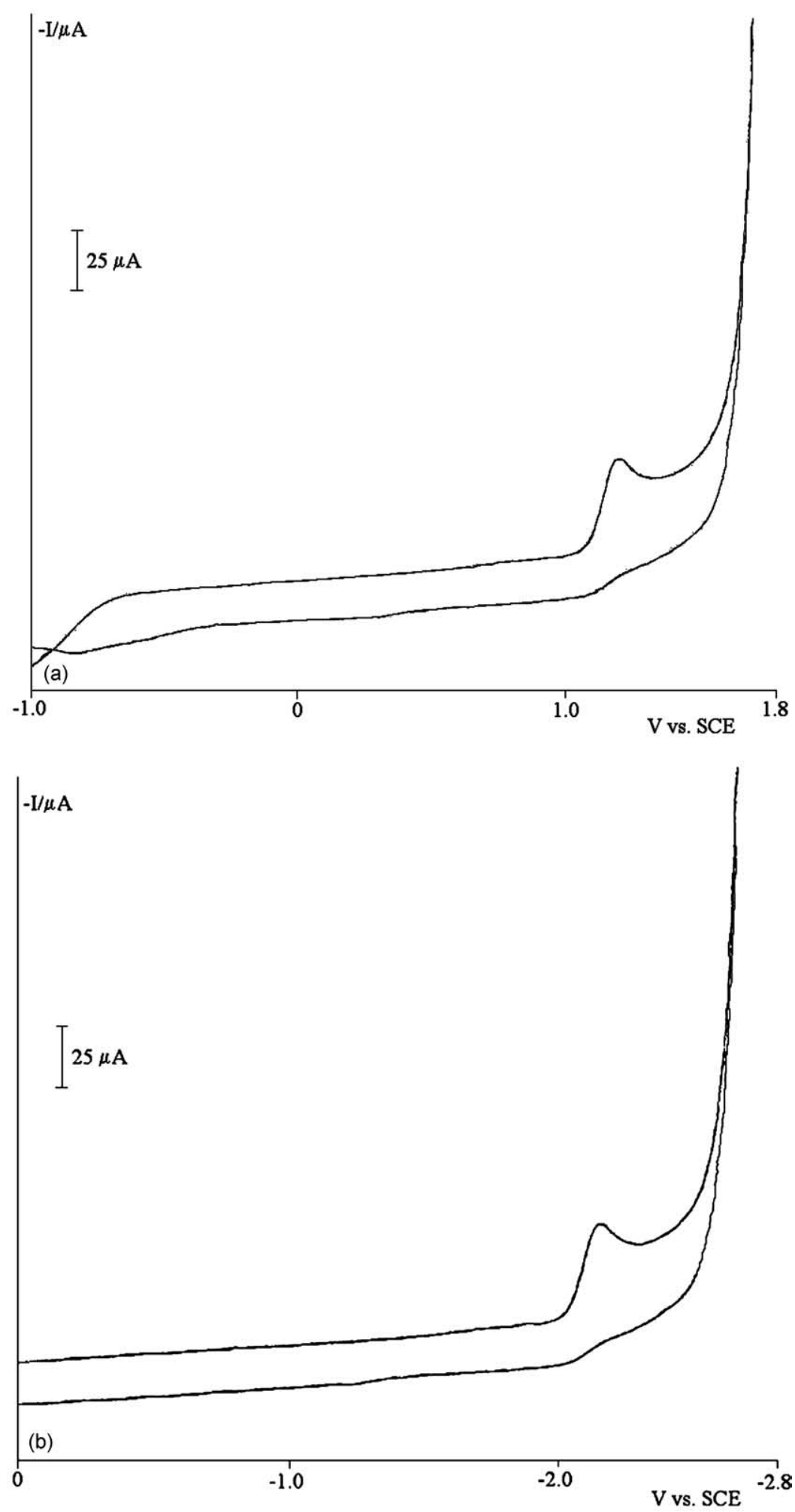

Figure 2. Cyclic voltammograms at a vitreous carbon electrode of a $0.005 \mathrm{~mol} \mathrm{dm}{ }^{-3}$ solution of compound 2 in $\mathrm{DMF}$ with $0.1 \mathrm{~mol} \mathrm{dm}^{-3} \mathrm{Bu}_{4} \mathrm{NBF}_{4}$ as supporting electrolyte at a sweep rate of $100 \mathrm{mV} \mathrm{s}^{-1}$ ( $\mathrm{SCE}=$ standard calomel electrode). 


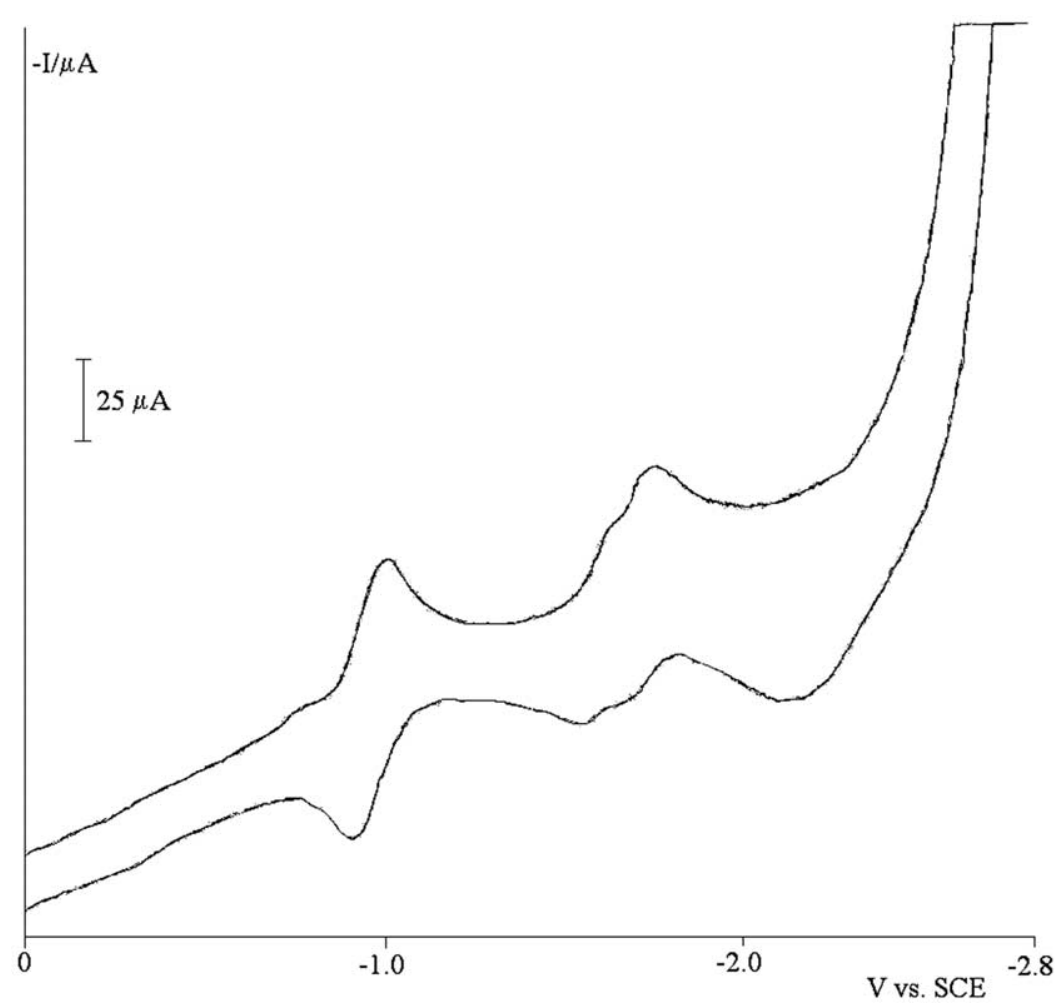

Figure 3. Cyclic voltammogram at a vitreous carbon electrode of a 0.005 mol dm ${ }^{-3}$ solution of compound $\mathbf{3}$ in $\mathrm{DMF}$ with $0.1 \mathrm{~mol} \mathrm{dm}^{-3} \mathrm{Bu}_{4} \mathrm{NBF}_{4}$ as supporting electrolyte at a sweep rate of $100 \mathrm{mV}^{-1}(\mathrm{SCE}=$ standard calomel electrode).

-1.00 and $-1.82 \mathrm{~V}$ versus SCE (Fig. 3). Considering the electron-withdrawing effect of the substituents, the first reduction potential for 2,5-bis-methoxycarbonylpyrazine is in agreement with that found for: unsubstituted pyrazine $(-2.16$ versus SCE $) ;{ }^{12} 2$-carboxamide pyrazine $(-1.75 \mathrm{~V}$ versus SCE); ${ }^{13}$ and with the first reduction peak of chloropyrazine $\left(-1.78 \mathrm{~V}\right.$ versus SCE). ${ }^{12}$

In view of the cyclic voltammetry data obtained, controlled potential electrolysis of compound $\mathbf{2}$ at the oxidation and reduction peak potentials were carried out. In these reactions tetraethylammonium chloride was used as supporting electrolyte and triethylammonium chloride as electron donor. Oxidation of compound 2 gave one of the diastereomers of $N, N$-bis-(tert-butoxycarbonyl)-2,3dichloro-2,5-bis-methoxycarbonyl-1,2,3,4-tetrahydropyrazine (compound 5) in 91\% yield (Scheme 3). The formation of this compound can be due to oxidation to give a radical cation which reacts with the chloride ions present in solution. Reduction of compound 2 gave as expected $N, N$ bis-(tert-butoxycarbonyl)-2,5-bis-methoxycarbonyl- 1,2,3,4-tetrahydropyrazine (compound 6) in 55\% yield (Scheme 3).

\section{Conclusion}

The common method for the synthesis of pyrazines involves the cyclocondensation of nitrogen nucleophiles onto $\boldsymbol{\alpha}$-dicarbonyl systems. We developed a new high yielding method for the synthesis of a 1,4-dihydropyrazine derivative from the methyl ester of $N$-(4-toluenesulfonyl)- $N$-(tertbutoxycarbonyl)- $\alpha, \beta$-didehydroalanine by treatment with DMAP and $\mathrm{K}_{2} \mathrm{CO}_{3}$. This compound was easily converted into 2,5-bis-carboxymethylpyrazine by treatment with TFA. The 1,4-dihydropyrazine derivative is also a good substrate for the diastereoselective synthesis of several tetrahydropyrazines, in good to high yields, either by Michael addition reactions or by controlled potential electrolysis. Several of these diazine derivatives can have biological activity since pyrazinamide is one of the front line agents against M. Tuberculosis ${ }^{14}$ some dihydropyrazines such as

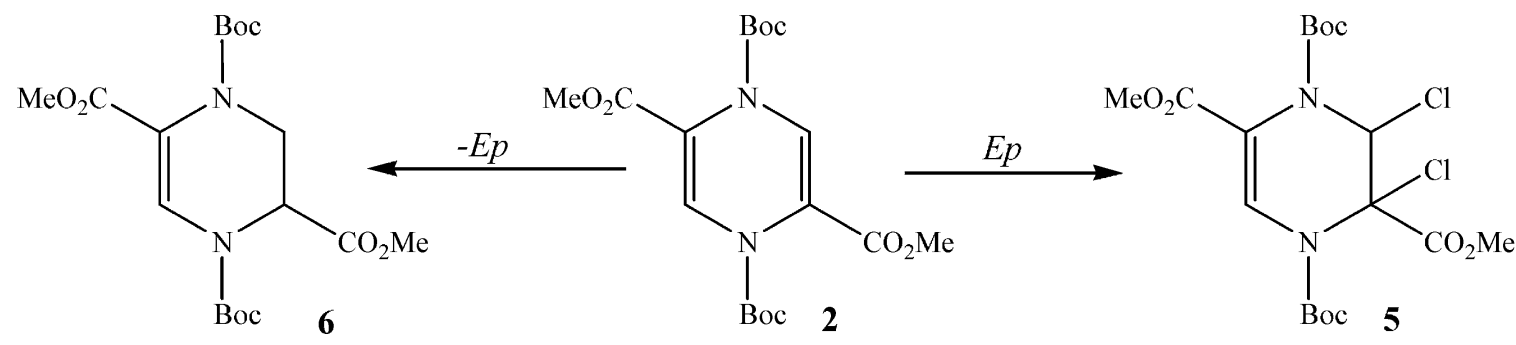

Scheme 3. 
2,3-dihydro-5,6-dimethylpyrazine showed DNA strandbreaking activity in plasmid $^{15}$ and tetrahydropyrazines have been used in the synthesis of a HIV protease inhibitor. ${ }^{16}$

\section{Experimental}

\subsection{Materials and methods}

Melting points were determined in a Gallenkamp apparatus and are uncorrected. ${ }^{1} \mathrm{H}$ and ${ }^{13} \mathrm{C}$ NMR spectra were recorded on a Varian Unity Plus at 300 and $75.4 \mathrm{MHz}$, respectively. ${ }^{1} \mathrm{H}-{ }^{1} \mathrm{H}$ spin-spin decoupling and DEPT $\theta 45^{\circ}$ were used. Chemical shifts are given in ppm and coupling constants in Hz. MS and HRMS data were recorded by the mass spectrometry service of the University of Vigo, Spain. Elemental analysis was performed on a LECO CHNS 932 elemental analyser.

The reactions were monitored by thin layer chromatography (TLC). Column chromatography was performed on Macherey-Nagel silica gel 230-400 mesh. Petroleum ether refers to the boiling range $40-60{ }^{\circ} \mathrm{C}$.

4.1.1. Synthesis of Tos- $\Delta \mathrm{Ala}(N$-Boc)-OMe. The synthesis of these compounds was described in Ref. 6.

4.1.2. Synthesis of $N, N$-bis-(tert-butoxycarbonyl)-2,5-bismethoxycarbonyl-1,4-dihydropyrazine (2) from Tos$\Delta \operatorname{Ala}(N$-Boc)-OMe. To a solution of Tos- $\Delta \operatorname{Ala}(N$-Boc)OMe in acetonitrile $\left(0.1 \mathrm{~mol} \mathrm{dm}^{-3}\right), \mathrm{K}_{2} \mathrm{CO}_{3}$ (6 equiv) was added, followed by 1 equiv of DMAP, with fast stirring at room temperature. The reaction was monitored by TLC, (diethyl ether $/ n$-hexane, 1:1) and when no starting material nor $\mathrm{Boc}-\Delta \operatorname{Ser}(O$-toluenesulfinyl)-OMe was detected $(\approx 72 \mathrm{~h}$ ), the solution was filtered and evaporated at reduced pressure (the same procedure but heating the reaction mixture under reflux allowed the reaction to be complete in $12 \mathrm{~h}$ ). The residue obtained was partitioned between $200 \mathrm{~cm}^{3}$ of diethyl ether and $100 \mathrm{~cm}^{3}$ of $\mathrm{KHSO}_{4}$ $\left(1 \mathrm{~mol} \mathrm{dm}^{-3}\right)$. The organic phase was thoroughly washed with $\mathrm{KHSO}_{4}\left(1 \mathrm{~mol} \mathrm{dm}{ }^{-3}\right), \mathrm{NaHCO}_{3}\left(1 \mathrm{~mol} \mathrm{dm}^{-3}\right)$ and brine $\left(3 \times 50 \mathrm{~cm}^{3}\right.$ each), and dried over $\mathrm{MgSO}_{4}$. Removal of the solvent afforded pure compound 2 (89\%), mp 155.0$156.0{ }^{\circ} \mathrm{C}$ (from diethyl ether $n$-hexane). ${ }^{1} \mathrm{H}$ NMR $\left(\mathrm{CDCl}_{3}\right)$ : $1.50\left(18 \mathrm{H}, \mathrm{s}, \mathrm{CH}_{3} 2 \mathrm{Boc}\right), 3.80\left(6 \mathrm{H}, \mathrm{s}, 2 \mathrm{CH}_{3} \mathrm{OMe}\right), 7.09$ $(2 \mathrm{H}, \mathrm{s}, 3-\mathrm{H}+6-\mathrm{H}) ;{ }^{13} \mathrm{C}$ NMR $\left(\mathrm{CDCl}_{3}\right): 27.88,52.27,83.65$, 119.82, 127.68, 148.82, 162.58; MS: $\mathrm{m} / \mathrm{z}(\%)=399(14)$ $\left[\mathrm{M}^{+}+1\right], 398(20)\left[\mathrm{M}^{+}\right], 343(36)\left[\mathrm{M}^{+}-\mathrm{CO}_{2} \mathrm{Me}\right], 298(6)$ $\left[\mathrm{M}^{+}-\mathrm{Boc}\right], 198$ (100) $\left[\mathrm{M}^{+}-2 \mathrm{Boc}\right]$. Anal. Calcd for $\mathrm{C}_{18} \mathrm{H}_{26} \mathrm{~N}_{2} \mathrm{O}_{8}$ (398.41): C 54.27; H 6.58; N 7.03; found $\mathrm{C}$ 54.42; H 6.72; N 6.94 .

4.1.3. Synthesis of $N, N$-bis-(tert-butoxycarbonyl)-2,5-bismethoxycarbonyl-1,4-dihydropyrazine (2) from TosSer-OMe. To a solution of Tos-Ser-OMe in dry acetonitrile $\left(0.1 \mathrm{~mol} \mathrm{dm}^{-3}\right), 0.1$ equiv of DMAP were added, followed by $\mathrm{Boc}_{2} \mathrm{O}$ (2.2 equiv) with fast stirring at room temperature. After reacting for 30 min more DMAP (1 equiv) was added and also $\mathrm{K}_{2} \mathrm{CO}_{3}$ (6 equiv). After reacting for approximately 3 days the same work-up as described above was carried out to give compound $\mathbf{2}$ ( $78 \%$ yield).
4.1.4. Synthesis of 2,5-bis-methoxycarbonylpyrazine (3). To a solution of compound $\mathbf{2}$ in dichloromethane $\left(0.02 \mathrm{~mol} \mathrm{dm}^{-3}\right), 10 \%$ trifluoroacetic acid was added with fast stirring at room temperature. The reaction was monitored by TLC, (diethyl ether $/ n$-hexane, $1: 1$ ) and when no starting material was detected removal of the solvent afforded pure compound 3 (71\%), $\mathrm{mp} 145.5-147.0^{\circ} \mathrm{C}$ (from diethyl ether $/ n$-hexane). ${ }^{1} \mathrm{H}$ NMR $\left(\mathrm{CDCl}_{3}\right): 4.10(6 \mathrm{H}, \mathrm{s}$, $\left.2 \mathrm{CH}_{3} \mathrm{OMe}\right), 9.42(2 \mathrm{H}, \mathrm{s}, 3-\mathrm{H}+6-\mathrm{H}) ;{ }^{13} \mathrm{C} \mathrm{NMR}\left(\mathrm{CDCl}_{3}\right)$ : 53.55, 145.18, 145.52, 163.52. Anal. Calcd for $\mathrm{C}_{8} \mathrm{H}_{8} \mathrm{~N}_{2} \mathrm{O}_{4}$ (196.16): C 48.98; H 4.11; N 14.28; found C 49.06; H 4.10; N 14.00.

4.1.5. Synthesis of $N, N$-bis-(tert-butoxycarbonyl)-2,5-bismethoxycarbonyl-3-(triazol-1-yl)-1,2,3,4-tetrahydropyrazine (4a). To a solution of compound 2 in acetonitrile $\left(0.1 \mathrm{~mol} \mathrm{dm}^{-3}\right), \mathrm{K}_{2} \mathrm{CO}_{3}$ (6 equiv) was added, followed by 1 equiv of 1,2,4-triazole, with fast stirring at room temperature. The reaction was monitored by TLC, (diethyl ether/n-hexane, $1: 1)$ and when no starting material was detected $(\approx 16 \mathrm{~h})$, the solution was filtered and evaporated under reduced pressure. The residue obtained was partitioned between $100 \mathrm{~cm}^{3}$ of diethyl ether and $30 \mathrm{~cm}^{3}$ of $\mathrm{NaHCO}_{3}\left(1 \mathrm{~mol} \mathrm{dm}^{-3}\right)$. The organic phase was washed with $\mathrm{NaHCO}_{3}\left(1 \mathrm{~mol} \mathrm{dm}{ }^{-3}\right)$ and brine $\left(2 \times 30 \mathrm{~cm}^{3}\right.$ each $)$, and dried over $\mathrm{MgSO}_{4}$. Removal of the solvent afforded compound $\mathbf{4} \mathbf{a}$ as an enantiomeric mixture of the trans diastereomer (92\%); oil; ${ }^{1} \mathrm{H}$ NMR $\left(\mathrm{CDCl}_{3}\right)$ (2 rotamers): $1.48,1.50\left(36 \mathrm{H}, 2 \mathrm{~s}, \mathrm{CH}_{3}\right.$ Boc), 3.79, $3.81\left(12 \mathrm{H}, 2 \mathrm{~s}, \mathrm{CH}_{3}\right.$ $\mathrm{OMe}), 5.93,6.03,6.93,6.99$ (4H, 4s, 2-H $+3-\mathrm{H}$ pyr.), 7.36, $7.57(2 \mathrm{H}, 2 \mathrm{~s}, 6-\mathrm{H}$ pyr. $), 7.92(2 \mathrm{H}, \mathrm{s}, 3-\mathrm{H}$ or $5-H$ triaz. $), 8.32$ (2H, s, $3-H$ or $5-H$ triaz.); ${ }^{13} \mathrm{C} \mathrm{NMR}\left(\mathrm{CDCl}_{3}\right): 27.69,27.83$, $52.15,53.12,56.26,57.40,63.20,83.79,84.37,122.46$, 127.64, 148.50, 150.04, 152.26, 166.72; MS: $\mathrm{m} / \mathrm{z}(\%)=467$ (7) $\left[\mathrm{M}^{+}\right], 367$ (3) $\left[\mathrm{M}^{+}-\right.$Boc], 267 (24) $\left[\mathrm{M}^{+}-2 \mathrm{Boc}\right], 198$ (100) $\left[\mathrm{M}^{+}-2\right.$ Boc-triaz.]; HRMS found 467.2016, Calcd for $\mathrm{C}_{20} \mathrm{H}_{29} \mathrm{~N}_{5} \mathrm{O}_{8} 467.2016$.

4.1.6. Synthesis of $N, N$-bis-(tert-butoxycarbonyl)-2,5-bismethoxycarbonyl-3-(3-formylindol-1-yl)-1,2,3,4-tetrahydropyrazine (4b). The same procedure described for the synthesis of compound 4a was applied substituting 3-formylindole for 1,2,4-triazole. Removal of the solvent afforded compound $\mathbf{4 b}$ as an enantiomeric mixture of the trans diastereomer $(90 \%), \mathrm{mp} 156.0-157.0^{\circ} \mathrm{C}$ (from ethyl acetate $/ n$-hexane). ${ }^{1} \mathrm{H}$ NMR $\left(\mathrm{CDCl}_{3}\right)$ (2 rotamers): 1.48 , $1.54\left(36 \mathrm{H}, 2 \mathrm{~s}, \mathrm{CH}_{3} \mathrm{Boc}\right), 3.75,3.84\left(12 \mathrm{H}, 2 \mathrm{~s}, \mathrm{CH}_{3} \mathrm{OMe}\right)$, $5.40,5.56(2 \mathrm{H}, 2 \mathrm{~s}, 2-\mathrm{H}$ or $3-\mathrm{H}$ pyr. $), 7.23-7.58(10 \mathrm{H}, \mathrm{m}, 2-\mathrm{H}$ or $3-\mathrm{H}+6-\mathrm{H}$ pyr. $+2-\mathrm{H}+5-\mathrm{H}+6-\mathrm{H}$ ind. $), 7.73(2 \mathrm{H}, \mathrm{d}, J=$ $7.5 \mathrm{~Hz}, 7-\mathrm{H}$ ind.), $8.31(2 \mathrm{H}, \mathrm{d}, J=7.8 \mathrm{~Hz}, 4-\mathrm{H}$ ind. $), 9.95$ $(2 \mathrm{H}, \mathrm{s}, \mathrm{CHO}) ;{ }^{13} \mathrm{C} \mathrm{NMR}\left(\mathrm{CDCl}_{3}\right): 27.73,27.92,52.12$, 53.39, 57.01, 59.95, 83.76, 85.32, 110.33, 110.65, 119.27, $121.69,122.13,123.67,124.84,125.13,134.17,136.60$, $150.41,151.83,163.91,166.70,184.94$. Anal. Calcd for $\mathrm{C}_{27} \mathrm{H}_{33} \mathrm{~N}_{3} \mathrm{O}_{9}$ (543.57): C 59.66; H 6.12; N 7.73; found $\mathrm{C}$ $59.87 ;$ H $6.18 ;$ N 7.78 .

4.1.7. Synthesis of $N, N$-bis-(tert-butoxycarbonyl)-2,5-bismethoxycarbonyl-3-(4-bromophenylsulfanyl)-1,2,3,4tetrahydropyrazine $(\mathbf{4 c})$. The same procedure described for the synthesis of compound 4a was applied substituting 4-bromothiophenol for 1,2,4-triazole. Removal of the solvent afforded compound $\mathbf{4 c}$ as an enantiomeric mixture 
of the trans diastereomer (76\%), mp 137.0-138.5 ${ }^{\circ} \mathrm{C}$ (from diethyl ether $n$-hexane). ${ }^{1} \mathrm{H}$ NMR $\left(\mathrm{CDCl}_{3}\right)$ (2 rotamers): $1.34,1.49,1.57\left(36 \mathrm{H}, 3 \mathrm{~s}, \mathrm{CH}_{3}\right.$ Boc $), 3.69,3.78(12 \mathrm{H}, 2 \mathrm{~s}$, $\left.\mathrm{CH}_{3} \mathrm{OMe}\right), 4.89,5.08(2 \mathrm{H}, 2 \mathrm{~s}, 2-\mathrm{H}$ or $3-\mathrm{H}), 6.15,6.21(2 \mathrm{H}$, $2 \mathrm{~s}, 2-\mathrm{H}$ or $3-\mathrm{H}), 7.48(8 \mathrm{H}$, broad s, ArH), 7.56, $7.78(2 \mathrm{H}, 2 \mathrm{~s}$, $6-\mathrm{H}) ;{ }^{13} \mathrm{C} \mathrm{NMR}\left(\mathrm{CDCl}_{3}\right): 27.66,28.00,51.83,52.87,57.30$, 57.60, 58.23, 59.77, 82.41, 84.29, 108,52, 122.44, 130.50, 132.04, 135.32, 150.67, 151.22, 164.26, 167.27. Anal. Calcd for $\mathrm{C}_{24} \mathrm{H}_{31} \mathrm{~N}_{2} \mathrm{O}_{8} \mathrm{SBr}$ (587.48): C 49.07; H 5.32; N 4.77; $\mathrm{S}$ 5.46; found C 49.40; H 5.52; N 4.81; S 5.40.

4.1.8. Synthesis of $N, N$-bis-(tert-butoxycarbonyl)-2,5-bismethoxycarbonyl-3-(benzylamino)-1,2,3,4-tetrahydropyrazine (4d). The same procedure described for the synthesis of compound $\mathbf{4 a}$ was applied substituting benzylamine for 1,2,4-triazole. Removal of the solvent afforded compound $\mathbf{4 d}$ as an enantiomeric mixture of the trans diastereomer (82\%), mp $106.5-107.5^{\circ} \mathrm{C}$ (from diethyl ether $/ n$-hexane). ${ }^{1} \mathrm{H} \mathrm{NMR}\left(\mathrm{CDCl}_{3}\right)$ (2 rotamers): $1.42,1.45$, 1.52 (36H, 3s, $\mathrm{CH}_{3}$ Boc), 3.70 (6H, s, $\left.\mathrm{CH}_{3} \mathrm{OMe}\right), 3.80-3.92$ $\left(10 \mathrm{H}, \mathrm{m}, \mathrm{CH}_{3} \mathrm{OMe}+\mathrm{CH}_{2} \mathrm{Bn}\right), 4.82,4.97$ (2H, 2s, 2-H or $3-\mathrm{H}), 5.60,5.65(2 \mathrm{H}, 2 \mathrm{~s}, 2-\mathrm{H}$ or $3-\mathrm{H}), 7.28-7.36(10 \mathrm{H}, \mathrm{m}$, $\mathrm{ArH}), 7.50,7.71(2 \mathrm{H}, 2 \mathrm{~s}, 6-\mathrm{H}) ;{ }^{13} \mathrm{C} \mathrm{NMR}\left(\mathrm{CDCl}_{3}\right): 27.87$, 27.97, 49.47, 51.77, 52.57, 59.27, 60.55, 62.41, 81.58, $84.02,121.51,127.25,128.43,128.56,139.17,150.69$, 152.75, 164.99, 167.85, 168.07. Anal. Calcd for $\mathrm{C}_{25} \mathrm{H}_{35} \mathrm{~N}_{3} \mathrm{O}_{8}$ (505.56): C 59.39; $\mathrm{H}$ 6.98; $\mathrm{N} \mathrm{8.31;} \mathrm{found} \mathrm{C}$ 59.43 ; H 7.21; N 8.05.

4.1.9. Synthesis of $N, N$-bis-(tert-butoxycarbonyl)-2,5-bismethoxycarbonyl-3-methoxy-1,2,3,4-tetrahydropyrazine (4e). The same procedure described for the synthesis of compound 4a was applied substituting sodium methoxide for 1,2,4-triazole. Removal of the solvent afforded compound $4 \mathbf{e}$ as an enantiomeric mixture of the trans diastereomer (35\%); oil; ${ }^{1} \mathrm{H}$ NMR $\left(\mathrm{CDCl}_{3}\right)$ (2 rotamers): 1.43, 1.47, $1.53\left(36 \mathrm{H}, 3 \mathrm{~s}, \mathrm{CH}_{3}\right.$ Boc $), 3.40\left(6 \mathrm{H}, \mathrm{s}, \mathrm{CH}_{3}\right.$ COMe), 3.70, 3.79 (12H, 2s, $\left.\mathrm{CH}_{3} \mathrm{COOMe}\right), 4.89,5.05(2 \mathrm{H}$, $2 \mathrm{~s}, 2-\mathrm{H}$ or $3-\mathrm{H}), 5.79,5.84(2 \mathrm{H}, 2 \mathrm{~s}, 2-\mathrm{H}$ or $3-\mathrm{H}), 7.51,7.72$ $(2 \mathrm{H}, 2 \mathrm{~s}, 6-\mathrm{H}),{ }^{13} \mathrm{C} \mathrm{NMR}\left(\mathrm{CDCl}_{3}\right): 27.85,28.01,51.77$, $52.70,55.26,58.78,60.18,77.96,82.02,83.56,83.91$, $107.85,122.47,150.81,167.37$; MS: $m / z(\%)=430(8)$ $\left[\mathrm{M}^{+}\right], 230(100)\left[\mathrm{M}^{+}-2 \mathrm{Boc}\right], 199(21)\left[\mathrm{M}^{+}-2 \mathrm{Boc}-\right.$ OMe]; HRMS found 430.1947, Calcd for $\mathrm{C}_{19} \mathrm{H}_{30} \mathrm{~N}_{2} \mathrm{O}_{9}$ 430.1951 .

4.1.10. Synthesis of $N, N$-bis-(tert-butoxycarbonyl)-2,3dichloro-2,5-bis-methoxycarbonyl-1,2,3,4-tetrahydropyrazine (5). A solution of $\mathrm{Et}_{4} \mathrm{NCl}\left(0.1 \mathrm{~mol} \mathrm{dm}^{-3}\right.$; supporting electrolyte) and $\mathrm{Et}_{3} \mathrm{NHCl}\left(0.04 \mathrm{~mol} \mathrm{dm}^{-3}\right.$; proton donor) in $\mathrm{MeCN}$ was added to a two compartment, three-electrode cell. Compound 2 (99.5 mg, $0.25 \mathrm{mmol})$ was added to the anodic compartment and a cyclic voltammogram recorded. The potential was adjusted to a value $50 \mathrm{mV}$ more positive than that corresponding to the $\mathrm{CV}$ peak and the electrolysis started, the reaction being monitored by HPLC. When all starting material had disappeared, the content of the anodic compartment was concentrated under reduced pressure and the residue partitioned between $100 \mathrm{~cm}^{3}$ of ethyl acetate and $50 \mathrm{~cm}^{3}$ of water. The organic phase was then washed with water and brine $\left(3 \times 30 \mathrm{~cm}^{3}\right.$ each $)$ and dried over $\mathrm{MgSO}_{4}$. The solution was filtered and the solvent removed to give a residue which was submitted to column chromatography using diethyl ether/n-hexane $(1: 2)$ as eluent to give compound $\mathbf{5}$ (106.8 mg, 91\%), mp 119.5-121.0 ${ }^{\circ} \mathrm{C}$ (from diethyl ether/ $n$-hexane). ${ }^{1} \mathrm{H} \mathrm{NMR}\left(\mathrm{CDCl}_{3}\right): 1.49,1.53\left(18 \mathrm{H}, 2 \mathrm{~s}, \mathrm{CH}_{3}\right.$ Boc), 3.82, 3.88 (6H, 2s, $\left.\mathrm{CH}_{3} \mathrm{OMe}\right), 6.61$ (1H, s, 3-H), 7.56 $(1 \mathrm{H}, \mathrm{s}, 6-\mathrm{H}) ;{ }^{13} \mathrm{C} \mathrm{NMR}\left(\mathrm{CDCl}_{3}\right): 27.70,27.76,52.24,54.24$, $68,71,83.93,85.91,109.74,122.00,126.15,148.79$, 149.05, 163.20, 163.68; MS: $m / z(\%)=470(1)\left[\mathrm{M}^{+}+2\right]$, 468 (1.3) $\left[\mathrm{M}^{+}\right], 368$ (2) $\left[\mathrm{M}^{+}-\mathrm{Boc}\right], 268$ (57) $\left[\mathrm{M}^{+}-\right.$ 2Boc], 233 (63) [ $\left.\mathrm{M}^{+}-2 \mathrm{Boc}-\mathrm{Cl}\right], 197$ (100) $\left[\mathrm{M}^{+}-2 \mathrm{Boc}-\right.$ $2 \mathrm{Cl}$. HRMS found 468.1082, Calcd for $\mathrm{C}_{18} \mathrm{H}_{26} \mathrm{~N}_{2} \mathrm{O}_{8} \mathrm{Cl}_{2}$ 468.1066 .

4.1.11. Synthesis of $N, N$-bis-(tert-butoxycarbonyl)-2,5bis-methoxycarbonyl-1,2,3,4-tetrahydropyrazine (6). The same procedure as described above was followed but adding compound $2(99.5 \mathrm{mg}, 0.25 \mathrm{mmol})$ to the cathodic compartment to give compound $6(55.2 \mathrm{mg}, 55.2 \%) .{ }^{1} \mathrm{H}$ NMR $\left(\mathrm{CDCl}_{3}\right): 1.41,1.52$ (18H, 2s, $\left.\mathrm{CH}_{3} \mathrm{Boc}\right), 2.96-3.08$ $(1 \mathrm{H}, \mathrm{m}, 3-\mathrm{H}), 3.71,3.78\left(6 \mathrm{H}, \mathrm{s}, 2 \mathrm{CH}_{3} \mathrm{OMe}\right), 4.68-4.90(2 \mathrm{H}$, $\mathrm{m}, 2-\mathrm{H}+3-\mathrm{H}), 7.53(1 \mathrm{H}, \mathrm{s}, 6-\mathrm{H}) ;{ }^{13} \mathrm{C} \mathrm{NMR}\left(\mathrm{CDCl}_{3}\right): 27.82$, 27.88, 42.27, 51.75, 52.62, 54.70, 55.98, 81.69, 83.58, $83.90,109.60,123.01,150.52,150.64,169.00,169.35$; MS: $m / z(\%)=400(4)\left[\mathrm{M}^{+}\right], 200(100)\left[\mathrm{M}^{+}-2 \mathrm{Boc}\right]$, 167 (11) $\left[\mathrm{M}^{+}-2\right.$ Boc-OMe $], 141$ (13) $\left[\mathrm{M}^{+}-2 \mathrm{Boc}-\right.$ $\mathrm{CO}_{2} \mathrm{Me}$; HRMS found 400.1857, Calcd for $\mathrm{C}_{18} \mathrm{H}_{28} \mathrm{~N}_{2} \mathrm{O}_{8}$ 400.1846 .

\section{Acknowledgements}

We wish to thank the Fundação para a Ciência e a Tecnologia for financial support (project no. POCTI/1999/QUI/32689).

\section{References}

1. (a) Jones, K.; Keenan, M.; Hibbert, F. Synlett 1996, 509-510. (b) Cavalier, J.; Marchand, C.; Rees, J.; Marchand-Brynaert, J. Synthesis 2001, 768-772.

2. Lotowski, Z.; Gryszkiewiez, A.; Borowiecka, J. B.; Nikitiuk, A.; Morzycki, J. W. J. Chem. Res., (S) 1999, 662-663.

3. Vazquez, J.; González, J. J. L.; Márquez, F.; Pongor, G.; Boogs, J. E. J. Phys. Chem., A 2000, 104, 2599-2612.

4. (a) Fourrey, J. L.; Beauhaire, J.; Yuan, C. W. J. Chem. Soc., Perkin Trans. 1 1987, 1841-1843. (b) Shu, C. J. Agric. Food Chem. 1999, 47, 4332-4335.

5. (a) Brook, D. J. R.; Haltiwanger, R. C.; Koch, T. H. J. Am. Chem. Soc. 1992, 6017, 6023. (b) Brook, D. J. R.; Noll, B. C.; Koch, T. H. J. Chem. Soc., Perkin Trans. 1 1998, 289-292.

6. Ferreira, P. M. T.; Maia, H. L. S.; Monteiro, L. S. Tetrahedron Lett. 1998, 39, 9575-9578.

7. Ferreira, P. M. T.; Maia, H. L. S.; Monteiro, L. S.; Sacramento, J. J. Chem. Soc., Perkin Trans. 1 2001, 3167-3173.

8. Ferreira, P. M. T.; Maia, H. L. S.; Monteiro, L. S. Eur. J. Org. Chem. 2003, 14, 2635-2644.

9. Abraham, R. J.; Reid, M. J. Chem. Soc., Perkin Trans. 2 2002, 1081-1091.

10. Kain, W. J. Am. Chem. Soc. 1983, 105, 707-713. 
11. Baumgarten, J.; Bessenbacher, C.; Kaim, W.; Stahl, T. J. Am. Chem. Soc. 1989, 111, 2126-2131.

12. Mubarak, M. S.; Peters, D. G. J. Electroanal. Chem. 2001, 507, 110-117.

13. Ragnarsson, U.; Grehn, L.; Maia, H. L. S.; Monteiro, L. S. Org. Lett. 2001, 3, 2021-2023.

14. Seitz, L. E.; Sulling, W. J.; Reynolds, R. C. J. Med. Chem. 2002, 45, 5604-5606.
15. Yamaguchi, T.; Eto, M.; Harano, K.; Kashibe, N.; Watanabe, K.; Ito, S. Tetrahedron 1999, 55, 675-686.

16. (a) Rossen, K.; Pye, P. J.; DiMichele, L. M.; Volante, R. P.; Reider, P. J. Tetrahedron Lett. 1998, 39, 6823-6826. (b) Rossen, K.; Weissman, S. A.; Sager, J.; Reamer, R. A.; Askin, D.; Volante, R. P.; Reider, P. J. Tetrahedron Lett. 1995, 36, 6419-6422. 